Taras Hryhorchuk,

$\mathrm{PhD}$, Associate Professor, Kyiv National University of Culture and Arts, 36, Konovatsia str., Kyiv, 01601

ORCID: 0000-0002-0395-1966

Halyna Aldankova,

$\mathrm{PhD}$, Associate Professor, Kyiv National University of Trade and Economics, 19, Kyoto str., Kyiv, 02156, Ukraine,

ORCID: 0000-0002-1962-4409

Researcher ID: N-2830-2016

Oksana Holik, $\mathrm{PhD}$, Associate Professor, Kyiv National University of Trade and Economics, 19, Kyoto str., Kyiv, 02156, Ukraine, ORCID: 0000-0002-0239-9292,

Researcher ID: N-1977-2016

\title{
GASTRONOMIC TOURISM AS AN ELEMENT OF SMALL TOWN TOURISM BRANDING
}

The article deals with the prerequisites for forming the tourist attractiveness of small cities and surrounding areas by realizing gastronomic tourism and the opportunities it provides. The process of becoming gastronomic tourism and features of its realization in our country are described. Our own algorithm for the implementation of the gastronomic tourism process has been put forward, where its elaborate elements will serve as the basis of the tourist brand of the place, which will provide creation, development and maintenance of a permanent voluntary connection with a strategically important group of tourists, due to the reliable set of features of gastronomic tourism of this city, the availability of consistently high quality and the expected level of satisfaction.

Keywords: gastronomic tourism, tourist attraction, small town branding, tourist area branding.

\section{Relevance of research topic.}

In times of permanent economic instability or turbulent processes not only in the tourism industry, but in other sectors of the national economies, there is a need to find mechanisms that can at least reduce levels of these negative phenomena. These problems are particularly acute for small administrative and territorial centers, which, 
unlike large settlements, where it is much easier to diversify influx of material and financial resources through reserves or attracting new commercial activities, have to suffer from declining income and decrease in the overall well-being of communities. It is even more difficult to confront these phenomena due to the openness of the modern world, where a dissatisfied consumer of touristic services can easily change direction of travel in search of new attractions within his scope of destinations of choice. Therefore, preservation of the touristic attractiveness of small cities in our country as well as support of their local brands is and will remain one of the most important factors of their economic development, and in our opinion, gastronomic tourism can be helpful here.

Formulation of the problem. The modern tourism industry is putting forward new challenges for its subjects, driven by the tremendous growth in the supply of tourism services. Globalization, blurring of interstate borders, high labor migration, informatization of society and others are major prerequisites for this. The above factors cause constant movement of people between continents, countries and regions, which, in turn, requires facilities for proper display of these places to guests and visitors. An ill-considered set of services in the offer is not capable of ensuring the attractive image of the region (city), and therefore misses the opportunity of local geographical branding by creating «anchors» of tourist attractions.

We are of the opinion that travel business nowadays is not only about tourist services for travelers, visits to museums, accommodation in standardized hotels and, particularly, dining in ordinary places with predictable cuisines. Gastronomic tourism can be a significant factor in creating and maintaining regional tourism brands, since in addition to growing consumer loyalty to new brands; it can actively influence the attraction of new categories of consumers.

\section{Analysis of recent researches and publications.}

Many researchers have devoted their work to the study of important aspects of gastronomic tourism. In particular, G. P. Green and M. L. Dougherty consider gastronomic tourism as a strategy for the development of local communities, the success of which is based on the popularization of local food [1]. D. Basyuk adheres to similar positions, emphasizing at the same time the possibilities of introducing tourism innovations under such conditions [2]. A. S. Karim and C. G. Q. Chi consider gastronomic tourism as a special attraction of tourist destinations [3]. The opinions of these authors are shared by Y. C. Lin, T. E Pearson and L. A. Sai, developing them to the level of formation, due to local food, of brand identity of a particular locality [4]. In the context of our study, it is extremely important for us to evaluate the prospects for the development of gastronomic tourism in our country. We see the coverage of these issues in the works of I. Komarnitsky [5] and H. Vyshnevska [6]. The authors substantiate the importance of gastronomic tourism as a factor in shaping the tourist attractiveness of both Ukraine as a whole and its individual regions. It is pointed out that gastronomic tourism is a powerful economic factor capable of creating new jobs; 
generating new financial revenues, and facilitating the identification of our country's socio-cultural heritage in today's globalized world.

Presentation of the main material. In order to prevent misunderstandings and individual subjective interpretations, we suggest abiding to the following definitions of the main categories. In particular, we are of the opinion that gastronomic tourism is a specific journey of an individual (or a group) with a view to getting connected with the socio-cultural heritage in the domain of culinary pursuits of communities in certain countries, regions and localities. Other tourist products are also expected to be consumed, although their value is inferior to the gastronomic appeal of the trip. The main categories of gastronomic tourism customers are usually: gourmets; culinary professionals; tourists who intend to increase the range of tourist services within one set; experts in evaluating culinary achievements and organizing new tours; free travelers; seekers of new experiences (adventures).

On the other hand, branding is the creation, development and maintenance of ongoing voluntary communication with a strategically important consumer group, through a stable and reliable set of excellent product features, due to the consistently high quality and the expected level of satisfaction [7]. From the point of view of small towns (small geographical territories, places), the quality of products and the level of satisfaction must be guaranteed by the institutions of these administrative and territorial units, and in our case by the local businesses in tourism and food industry.

In practice, well-organized place branding is a strategy or even a policy of enhancing the competitiveness of administrative and territorial units to attract investors, tourists, new residents and the like. It is based on the idea of communicating the uniqueness of a certain territory to the wide audience of existing and potential customers. It is this approach that enables the formation of the identity of the designated places and territories, their isolation and positioning among the competitive offers, which is often aided by gastronomic tourism.

Gastronomic tourism is a serious phenomenon which should not be taken lightly, as it is connected with the study of world culture and identities of particular peoples through their national cuisines. It is widely known that practically all travelers and pioneering explorers were introduced to the peculiarities of local food of different nations. Their impressions often became the basis for describing the traditions of aboriginal peoples.

The official date of origin of gastronomic tourism is 1998. At that time, the new term «culinary tourism» was registered at the Department of Folk Culture of Bowling Green State University. This marked the beginning of extensive research by scientists around the world. Eventually in 2006 the International Institute of Culinary Tourism was founded in America.

However, the soil for such an American breakthrough in this matter was prepared by the Italians, who simply did not have time to put their expertise into 
science. They were the first to come up with tourist flows to their country, creating diverse communities of interest under the banner of delicious food [8].

But how did gastronomic tourism in Ukraine develop, did it become a significant factor in shaping the tourist attractiveness of its individual places? Obviously, the answer to this question is complex and often ambiguous, notwithstanding the unsurpassed hospitality of our people.

Today, many may believe that gastronomic tourism in our country could not develop properly, as Ukraine was behind the «iron curtain» within the USSR, which impeded the logistics of tourist flows through its territories. And even since the declaration of independence, foreign tourists have been quite sluggish in developing touristic paths to the country unknown to them. The process of getting to know potential visitors continues. On the other hand, the constant shortage of essential foods has curbed the creation of culinary dishes that can provide a sense of uniqueness to local cuisines. It only discontinued at the threshold of the 2000s.

However, even in the times of the USSR, elements of gastronomic tourism of certain administrative-territorial units were there. Among the known facts are at least two phenomena of the city of Kyiv: the Kyiv cake and the Kyiv chicken cutlet. Eyewitnesses recall that of a special value for residents of almost all of the Soviet Union was considered a tourist trip, or at least a business trip to Kiev, since it was exactly there that you could taste those goodies, and if you were lucky - bring a real Kyiv cake home with you.

The cities of Poltava, Cherkasy, and Kirovograd regions were attracted by their incomparable halushky and varenyky. Hutsulshchyna and Pokuttia called for lovers of banush, huslianka and sheep cheese. All towns on the Black Sea coast could please the discerning gastronomic connoisseurs with exquisite fish dishes. Well, borscht, in its local interpretation is known as a representative dish of almost every settlement in Ukraine. That is why the inhabitants of the spacious USSR, and occasionally rare foreign guests, sought ways to visit our country to taste the dishes of its local cuisines as much as anything else.

Today, gastronomic tourism in our country opens up new opportunities. And one can see significant revival in this area. To name a few, here are just some of the strategically important solutions for branding small towns in Ukraine.

Holiday in Rakhiv. Celebration of Brynza (brynza - sheep cheese). Brynza - as softly and affectionately this cheese is called by hutsuls. For them, it is not so much a product, a dish, a gastronomic supplement (it is only one of many of its incarnations), but a completely transcendent phenomenon. For ages, ever since sheep were grazing in the Carpathian Mountains and shepherds raising to the polonynas (highland valleys), brynza determined the life and lifestyle of highlanders, their peculiarities of thinking and world perception. It was so. And so it is - time has not changed this world too much. At least part of the Transcarpathian Rakhiv still lives by shepherding and sheepskin dressing, dependent on the season. One of the hallmarks of autumn is the Hutsul Bryndzia Festival. The festival date coincides with the anniversary of Rakhiv founding [9]. 
The «Borsch'yiv» (literally, did you eat borscht) Borscht Festival is held annually in the Borshchiv Vyshyvanka Festival on the central square of the Borshchiv town, which in September becomes the capital of Ukrainian cuisine. Local housewives compete in the preparation of national dishes, which in ancient times gave the name to this small town. Within the Borshch'yiv festival, each settlement of the Borshchiv district presents its borscht, which is cooked by local hosts to original recipes. About 50 kinds of borscht are known in total. In addition, borscht traditionally cooked in a large cauldron on the open fire is served, which can be tasted by all the visitors [10].

In the Carpathian Kolomyya a contest «Delicious business card» was held to try and find the culinary brand of the city. Kolomyyas' natchynka with grilled meat has finally become one, which from now on will be offered at all city food establishments, at local fairs and festivals [11].

In the small town of Korosten, the autumn feast - the Derun Day festival is held every second Saturday of September. It is an unforgettable journey into the world of national traditional cuisine, spiced with extraordinary Ukrainian flavor, decorated with Korosten's identity and hospitality. Competitions for the best piece of art, anecdote, poem, parody of folk song are held within the festival. Everything is obviously linked to the theme of deruns (potato pancakes). The main competition of the festival is therefore, a competition for the best derun. A separate competition is run among the tasters - the one for the largest number of tasted pancakes.

There are also competitions in the Derunary triathlon during the festival, which include throwing pancakes into a bowl with sour cream from the distance of 5 meters, throwing a potato «miracle» at a competitor from 5 meters, Derunary Powerlifting squats with two heavy jugs full of pancakes.

These activities take place among historical monuments: Princess Olga's bathing tubs, the residence of Prince Mala, next to the monuments of Dobryna Mykytovych, Princess of Malusha Drevlyany, wife of Prince Svyatoslav with his young son Volodymyr, and the unique underground granite fortification [12].

In fact, all the practices described above are aimed at forming local regional brands that actively use the opportunities of gastronomic tourism to achieve their goals. Sometimes they are embodied without deep reflection, solely based on the desire to glorify their land, with the aim of pursuing certain political goals, from the standpoint of philanthropy, etc. However, as practice shows, such approaches are not sufficient. In these circumstances, it is advisable to take actions that can fully ensure the consistency of the decisions made, which will help to create a successful brand of the city or locality. In our opinion, this is possible if the following steps are carefully considered.

1. Promoting the conscious purpose of using the elements of gastronomic tourism in the context of the tourist attractiveness of the city, region and its brand. The expected temporary effect, as a rule, will not facilitate the realization of the gastronomic component in tourism as a factor of increasing the tourist attractiveness of 
the area. That is, the gastronomic component should be clearly distinguished and certainly contribute to the desire of customers to visit this destination in the future.

2. Presentation of reliable data. The gastronomic value of a visit to a particular place should be based on sincerity and truth, since all other approaches will only lead to a negative result for the branding of the area. For it is obvious that a quick delight of the taste of food, leading to health problems afterwards will not help generate positive consumer emotions at all.

3. Consistency with customer expectations and brand development goals. It is important to point out here that customers expect to satisfy their gastronomic needs at no risk to their health or safety. Deviation from these expectations will lead to customer dissatisfaction and, as a consequence, the choice of other places to visit. In the end, the local brand will suffer.

4. Consideration of community interests. Gastronomic tourism should be of interest not only to individual market players but also to the community at large. If well-organized along business processes it is capable of addressing a number of economic, social, and sometimes political problems.

5. Creativity, innovation and tradition. Gastronomic tourism should help to identify and support talents and skills in the local communities. At the same time, while new approaches to such activities should be implemented, the traditional component should remain.

6. Ways to present gastronomic tourism products. Almost all tourist destinations are visited by a variety of target audiences. They may differ in a variety of features that may even be unknown to the operator. That is why one should always have a number of additional or spare options in the range of services for tourists in order to ensure their maximum satisfaction, and as a result - their loyalty .

7. Ensuring the formation of communication flows. Gastronomic tourism, as a phenomenon that is capable of generating instant positive emotions, should provide opportunities for immediate dissemination of information about the obtained level of satisfaction, because it is a significant factor in shaping the image of a local brand. This factor is an additional element of effective branding that at the same time disciplines the operator to prevent a poor quality offer.

It is obvious that the above steps of forming an introductory system to gastronomic tourism as a branding element for a city or any other administrativeterritorial unit must be adjusted to the specific local conditions. The most important among the main factors for the introduction of gastronomic tourism will be: economic, infrastructural and political. That is, the territory introducing gastronomic tourism as a branding element should have sufficient funds for its organization, a proper system of logistics of tourist flows and a clear conviction of the local authorities that gastronomic tourism can become a «cherry on the cake» for visitors of their places.

Conclusion. We strongly believe that gastronomic tourism is one of the most important prerequisites for shaping touristic attractiveness of domestic territories and 
local tourism brands. The well-thought and considered introduction of gastronomic tourism will create preconditions for the economic growth of the regions, help resolve multiple social problems and actively spread cultural achievements of the country's regions. Notably, foundations of cultural identity of local destinations will be formed on the globalized tourist map of the world, which will attract new tourist flows.

\section{REFERENCES}

1. Green G.P., Dougherty M.L. (2008). Local iting link ages for food and tourism: culinary tourism as a community development strategy. Community Development, 39(3); pp. 148-158.

2. Basyuk D. I. (2012). Innovatsiynyy rozvytok hastronomichnoho turyzmu v Ukrayini. Naukovi pratsi NUKHT. Basyuk D. I. Innovatsiynyy rozvytok hastronomichnoho turyzmu v Ukrayini. [Innovative development of gastronomic tourism in Ukraine]. Scientific works of NUFT. No. 45. pp. 128-132.

3. Karim A.S., Chi C.G.Q. (2010). Culinary Tourism as a Destination Attraction: An Empirical Examination of Destinations' Food Image. Journal of Hospitality Marketing \& Management, 19: (6), pp. 531-555.

4. Lin Y.C., Pearson T.E., Cai, L.A. (2011). Food as a Form of Destination Identity: A Tourism Destination Brand Perspective. Tourism and Hospitality Research, 11: (1), pp. 30-48.

5. Komarnits'kyy I. O. (2011). Kulinarnyy turyzm v Ukrayini: stan i perspektyvy rehional'noho rozvytku v konteksti Yevro-2012 [Culinary tourism in Ukraine: the state and prospects of regional development in the context of Euro-2012]. Geography and tourism. No. 14, pp. 100-115.

6. Vyshnevs'ka H. H. (2013). Potentsial kulinarnykh turiv u konteksti spetsializovanoho turyzmu. [The potential of culinary tours in the context of specialized tourism]. Actual problems of the history, theory and practice of artistic culture. Kyiv, National Academy of Art and Culture Leadership, Iss. 31, pp. 112-118.

7. Hryhorchuk T. V. (2018). Brendynh. [Branding]. Kyiv: KNUKiM Publishing Center, pp. 7-8. (in Ukrainian).

8. Allyayn A. (2019) Hastronomichnyy turyzm: cherez yizhu do kul'tury. [Gastronomic tourism: through food to culture] / Available at: https://theoutlook.com.ua/ article/6337/ gastronomichnij-turizm-cherez-jzhu-do-kulturi.html. (accessed 27 Fabruary 2020).

9. Saga: turystychnyy operator. Svyato v Rakhovi. Svyato brynzdy [Holiday in Rakhiv. Holiday of drynza]. Available at: https://www.saga.ua/43_articles showarticle_2310.html. (accessed 27 Fabruary 2020).

10. Doroga.UA. Prazdnik «Borshchevskaya vyshivanka» i festival' «Borshch'İच» [Holiday «Borshchevskaya Vyshivanka» and the festival «Borshch'yiv»]. Available at: http://www.doroga.ua/Pages/Events.aspx?EventID=694. (accessed 27 Fabruary 2020).

11. Ukrinform. Mul'tymediyna platforma inomovlennya Ukrayiny. Kolomyya obrala sobi «Smachnu vizytku» [Kolomyia chose a Delicious Business Card]. Available at: https://www.ukrinform.ua/rubric-tourism/2751634-kolomia-obrala-sobismacnu-vizitivku.html. (accessed 27 Fabruary 2020).

12. Turystychna kompaniya «TamTur». Korosten'. Festyval' deruniv [Derun Festival]. Available at: https://tamtour.com.ua/korosten-festyval-deruniv. (accessed 27 Fabruary 2020). 